\title{
Morphological aspects of the genitalia of seven species of Heilus Kuschel (Coleoptera, Curculionidae)
}

\author{
Geane Brizzola dos Santos ${ }^{1} \&$ Germano Henrique Rosado-Neto²
}

\begin{abstract}
${ }^{1}$ Programa Nacional de Pós-Doutorado, Pós-Graduação em Ecologia e Conservação da Biodiversidade, Instituto de Biociências, Universidade Federal do Mato Grosso, Av. Fernando Correa da Costa s/n, 78060-900 Cuiabá-MT, Brazil. gbrizola@yahoo.com.br

²Departamento de Zoologia, Universidade Federal do Paraná. Caixa Postal 19020, 81531-980 Curitiba-PR, Brazil. rosadoneto@ufpr.br
\end{abstract}

\begin{abstract}
Morphological aspects of the genitalia of seven species of Heilus Kuschel (Coleoptera, Curculionidae). Morphological aspects of the male and female genitalia and their associated sclerites, abdominal tergite and sternite 8 , are described, illustrated and discussed for seven species of Heilus Kuschel 1955 of tribe and subtribe Hylobiini-Hylobiina. The seven species are $H$. faldermanni (Boheman, 1836); H. fasciculatus (Boheman, 1843); H. freyreissi (Boheman, 1836); H. myops (Boheman, 1836); $H$. pupillatus (Olivier, 1790); H. rufescens (Boheman, 1836) and H. tuberculosus (Perty, 1832).
\end{abstract}

KEYWORDS. Heilus; Hylobiini; morphology.

RESUMO. Aspectos morfológicos da genitália de sete espécies de Heilus Kuschel (Coleoptera, Curculionidae). Aspectos morfológicos da genitália masculina e feminina e seus escleritos associados, tergito e esternito abdominal 8, de sete espécies de Heilus Kuschel 1955 da tribo e subtribo Hylobiini-Hylobiina, são descritos, ilustrados e discutidos. As sete espécies são $H$. faldermanni (Boheman, 1836); H. fasciculatus (Boheman, 1843); H. freyreissi (Boheman, 1836); H. myops (Boheman, 1836); $H$. pupillatus (Olivier, 1790); H. rufescens (Boheman, 1836) e H. tuberculosus (Perty, 1832).

PALAVRAS-CHAVE. Heilus; Hylobiini; morfologia.

Kuschel (1955) undertook the most inclusive treatment of Neotropical Hylobiini and in there established seven new genera, Haplogenus, Heilipodus, Heilus, Marshallius, Parabyzes, Placeilipus and Rhineilipus. The genera were described in a key followed by a list of species placed in each genus. The actual diagnoses are the same as those originally presented by Kuschel, as until the present none have been revised. Heilus, one of these new genera, was defined by Kuschel (1955, page 292) by the presence of the following featur e, "first abolm in 1 ve it rite with a ba sal crease he avi ly dilated in the back of metacoxae, forming a reasonably sharp angle with the edge of which clearly extends over the above mentioned crease". Heilus is represented by 18 species, with 4 species occurring in Central America (O’Brien \& Wibmer 1982) and 14 species inhabiting in South America, of which 11 species are reported for Brazil (Wibmer \& O’Brien 1986).

Howden (1995, 1996), Wanat (2007) and Gaiger \& Vanin (2008) have recently highlighted the need to publish more studies on weevil genitalia and associated sclerites. Thus, taxonomic studies are fundamental to find new characteristics to confirm and improve the diagnosis of these genera. Here we describe and illustrate the male and female genitalia of seven species of Heilus and thereby provide new information for future taxonomic and cladistic studies of this and other Neotropical Hylobiini genera.

\section{MATERIAL AND METHODS}

We have examined 41 specimens of Heilus pertaining to seven species. All the specimens were loaned from the
Entomology Collection “Pe. J.S. Moure”, Departamento de Zoologia, Universidade Federal do Paraná, Curitiba, Brazil. The species included in this study are listed as follows: $H$. faldermanni (Boheman, 1836), H. fasciculatus (Boheman, 1843), H. freyreissi (Boheman, 1836), H. myops (Boheman, 1836), H. pupillatus (Olivier, 1790), H. rufescens (Boheman, 1836) and $H$. tuberculosus (Perty, 1832).

The dry specimens were boiled in water for some minutes to soften the tissue. The genitaliae were prepared after removal from the abdomen. After that, the latter was cut laterally, along the pleural region and the terga were pulled out. The genitalia were then removed, boiled in potassium hydroxide solution (KOH) at $10 \%$ to disintegrate the fat and the soft tissues and examined through a stereomicroscope.

At the end of the study, after drying the abdomen was then placed in the body of the same specimen from which it had been removed and the genitalia were stored in plastic microvials with glycerin to prevent them from drying up. They were mounted on the same pin as the dissected sample in both cases. The terminology used for this study was that employed by Thompson (1992) for male genitalia and Howden (1995, 1996) and Gaiger \& Vanin (2008) for female genitalia.

\section{RESULTS}

\section{Heilus faldermanni (Boheman, 1836)}

(Figs. 1, 8, 15, 24, 35, 42)

Female

Abdominal tergite 8 (Fig. 01) trapezoid, shorter than 

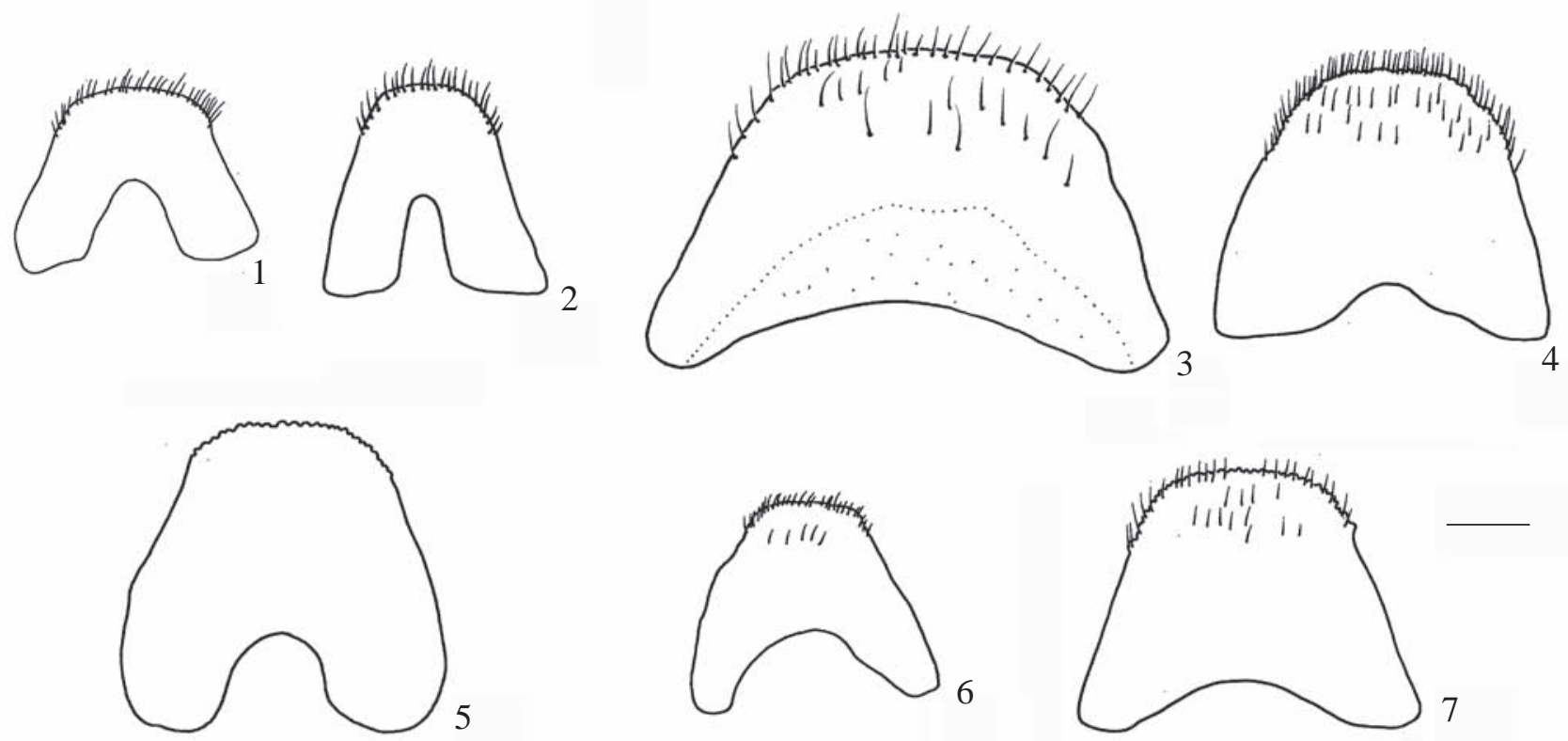

Figs. 1-7. Female genitalia, abdominal tergite 8 (dorsal view): 1. H. faldermanni, 2. H. fasciculatus, 3. H. freyreissi, 4. H. myops, 5. H. pupillatus, 6. H. rufescens, 7. H. tuberculosus. Bar: $1 \mathrm{~mm}$.

wide at base; slightly converging laterally towards the apex; smooth apical edge with few short, thin bristles. Abdominal sternite 8 (Fig. 08) with transverse apical lobes, shorter than the spiculum ventrale, rounded sides, apical edge with a fringe of thin elongated bristles; spiculum ventrale slightly wider on the base. Coxites (Fig. 15) elongated, wider on the base, with few short and thin bristles. Stylus cylindrical (Fig. 15), short, pubescent on the apex. Bursa copulatrix (Fig. 15) membranous, wide, with no sclerites, same size as the vagina. Spermathecal duct very short, much shorter than the spermatheca, insertion point on ventral base of bursa copulatrix next to the common oviduct; spermathecal capsule elongated, curved, slight protuberant ramus, collum longer than the cornu (Fig. 15). Spermathecal gland (Fig. 15) elongated, progressively enlarging to the apex.

\section{Male}

Aedeagus(Fig. 24): median lobe shorter than the apodemes, with subparallel sides, rounded next to the apex, nearly truncate at apex, with the presence of short, thin bristles, in moderate quantity. Tegmen (Fig. 35) with short, dorsal lobes broadly separated; manubrium slightly longer. Abdominal sternite 8 (Fig. 42) with subtransverse subtriangular plates, apical margin with long bristles in moderated quantity. Spiculum gastrale wide, straight, only slightly curved on the base, asymmetric apex (Fig. 42).

\section{Heilus fasciculatus (Boheman, 1843)}

(Figs. 2, 9, 16, 20, 25, 36, 43)

Female

Abdominal tergite 8 (Fig. 2) subtriangular elongated, as long as wide at base ; sides converging slightly towards the apex; apical margin rounded, smooth; bristles thin, short, in moderated quantity. Abdominal sternite 8 (Fig.
9) with apical lobes jointly transverse, rounded sides, with moderate quantity of elongated thin bristles on the apical margin, spiculum ventrale slender, twice as long as the apical lobes. Coxites (Fig. 16), elongated, cylindrical, glabrous. Stylus (Fig. 16) cylindrical, short, pubescent on the apex. Bursa copulatrix (Fig. 16) about twice as long as the vagina, without sclerites. Spermathecal duct very short, slightly shorter than the spermatheca, insertion point in the base of the bursa copulatrix, slightly more distant from the common oviduct. Spermatheca falciform (Fig. 20), ramus indistinct, collum shorter than the cornu. Spermathecal gland (Fig. 20) membranous, elongated.

\section{Male}

Aedeagus (Fig. 25): median lobe shorter than the apodemes; subparallel sides, rounded next to the apex; apical margin slightly narrowed, smooth, glabrous. Tegmen (Fig. 36) with dorsal lobes broadly separated, short, as long as the manubrium. Abdominal sternite 8 (Fig. 43) with transversal plates subtriangular, with moderate presence of long bristles. Spiculum gastrale wide, slightly curved on the base, asymmetric apex (Fig. 43).

\section{Heilus freyreissi (Boheman, 1836)}

(Figs. 3, 10, 17, 26, 37, 44)

Female

Abdominal tergite 8 (Fig. 3) subtrapezoid, transverse, apical margin smooth covered with short, thin and few bristles. Abdominal sternite 8 (Fig. 10) with apical lobes elongated, sinuous sides on the base, narrow next to the apex, smooth and with a moderate quantity of elongated bristles at the apex; spiculum ventrale slightly longer than the apical lobes, narrow and straight on the base, progressively enlarging towards the apical lobes. Coxites (Fig.17) elongated, cylindrical, 


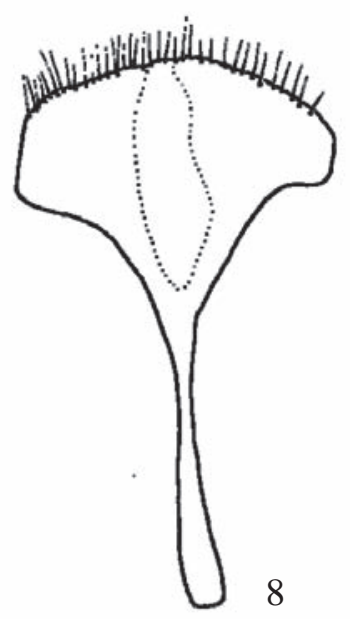

8

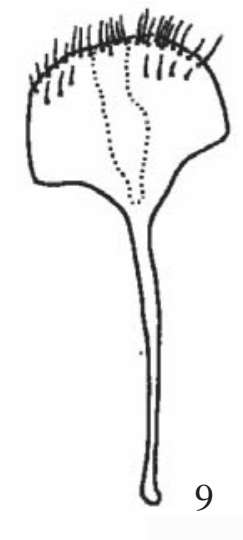

9
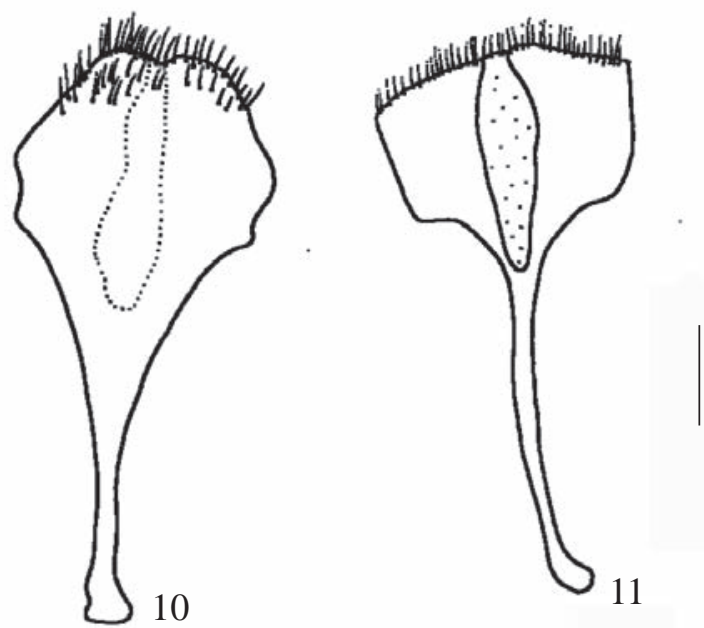
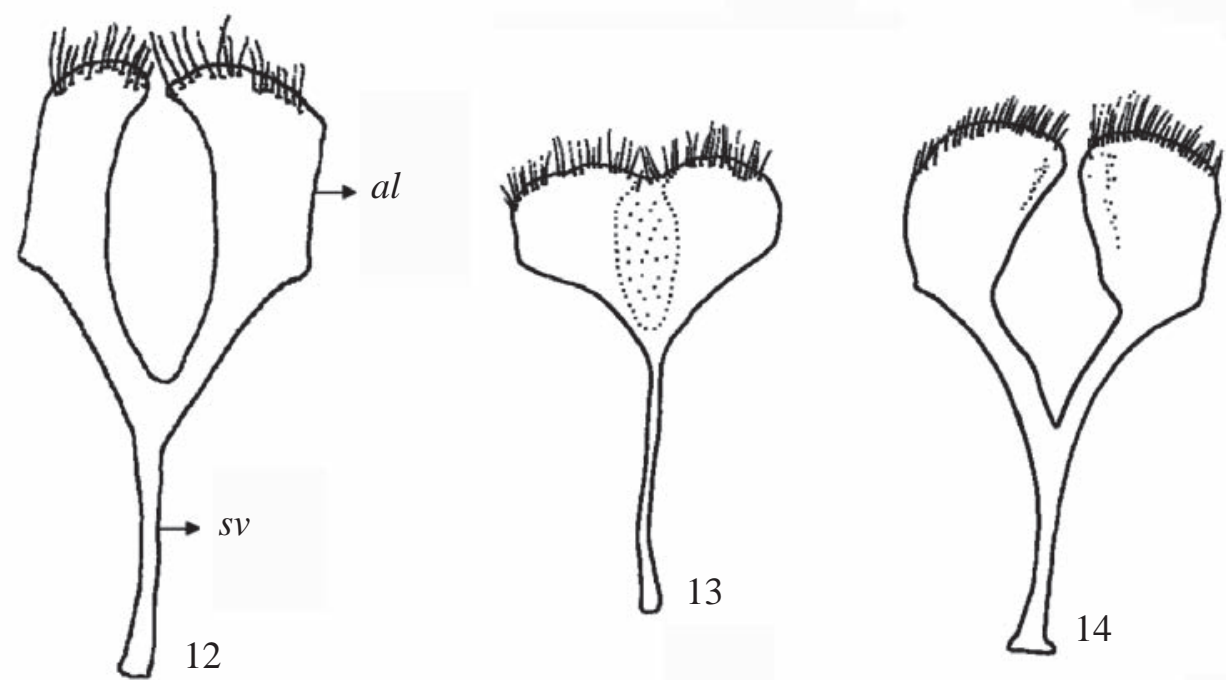

Figs. 8-14. Female genitalia, Abdominal sternite 8 (dorsal view): 8. H. faldermanni, 9. H. fasciculatus, 10. H. freyreissi, 11. H. myops, 12. H. pupillatus, al: apical lobe, sv: spiculum ventrale, 13. H. rufescens, 14. H. tuberculosus. Bar: $1 \mathrm{~mm}$.

glabrous. Stylus (Fig.17) cylindrical, short, with moderate quantity of bristles on the apex. Bursa copulatrix (Fig.17) slightly shorter, narrower than the vagina, with no sclerites. Spermathecal duct very short, shorter than the spermathecal gland and subequal to the spermatheca length, inserted at the base of the bursa copulatrix next to the common oviduct; spermathecal capsule curved, ramus well distinct, collum slightly shorter than the cornu. Spermathecal gland (Fig. 17) membranous, elongated.

\section{Male}

Aedeagus (Fig. 26): median lobe shorter than the apodemes; parallel sides, rounded apex, with a slight depression on the median region; presence of few and short bristles. Tegmen (Fig. 37) with short dorsal lobes broadly separated, manubrium slightly wider and subequal to the dorsal lobes in length. Abdominal sternite 8 (Fig. 44) with transversal plates, subtrapezoid, apical margin densely pubescent. Spiculum gastrale long, narrow, with a curved base, asymmetric apex (Fig. 44).

\section{Heilus myops (Boheman, 1836)}

(Figs. 4, 11, 18, 19, 25, 27, 28, 38)

\section{Female}

Abdominal tergite 8 (Fig.4) trapezoid, slightly converging laterally towards the apex; apical margin with short, thin, bristles, in moderate quantity. Abdominal sternite 8 (Fig.11) with transverse apical lobes, short, parallel sides, densely pubescent apically; shorter than the spiculum ventrale; this spicule almost twice as long as the apical lobes, slightly curved base. Coxites (Fig. 19) elongated, cylindrical, lateroapically pubescent. Stylus (Fig. 19) cylindrical, short, pubescent on the apex. Bursa copulatrix (Fig. 18) ample, longer than the vagina, with no sclerites. Spermathecal duct very short, slightly shorter than the spermathecal gland and subequal to the spermatheca length, insertion point next to the subterminal portion of the bursa copulatrix, very distant from the common oviduct; curved spermathecal capsule; ramus indistinct, collum slightly shorter than the cornu the latter 

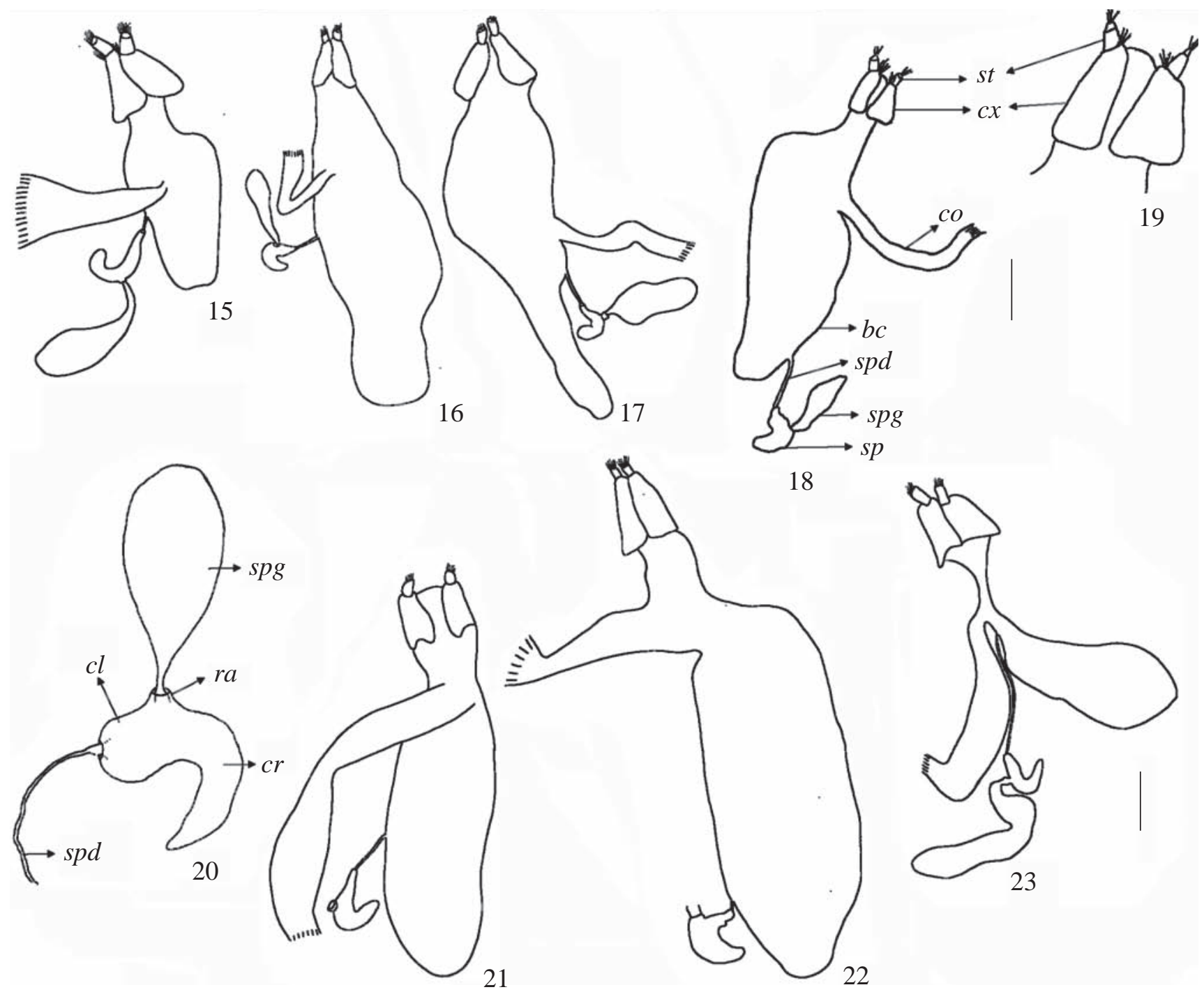

Figs. 15-23. Female genitalia, bursa copulatrix (latero-dorsal view): 15. H. faldermanni, 16. H. fasciculatus, 17. H. freyreissi, 18, 19. H. myops, st: stylus, cx: coxite, co: comum oviduct, bc: bursa copulatrix, spd: spermathecal duct, spg: spermathecal gland, sp: spermatheca, 20. H. fasciculatus, spg: spermathecal gland, ra: ramus, cl: collum, cr: cornu, spd: spermathecal duct, 21. H. pupillatus, 22. H. rufescens, 23. H. tuberculosus. Bar: 1 mm.

being globular; spermathecal gland (Fig. 18) membranous, slightly elongated.

\section{Male}

The median lobe of aedeagus (Figs. 27 and 28) slightly shorter than the apodemes; subparallel sides, rounded next to the apex; apical margin rounded, glabrous, non-curved in profile view. Tegmen (Fig. 38) with dorsal lobes broadly separated, short, subequal to the manubrium. Abdominal tergite 8 and spiculum gastrale not observed.

\section{Heilus pupillatus (Olivier, 1790)}

(Figs. 5, 12, 21, 29, 30, 39, 45)

\section{Female}

Abdominal tergite 8 (Fig. 5) trapezoid, sides slightly converging to the apex; slightly crenulate at base and glabrous on the apical margin. Abdominal sternite 8 (Fig. 12) with apical lobes and spiculum ventrale subequal in length; apical lobes with parallel sides, rounded next to the apex; apex with thin and long bristles; spiculum ventrale narrow and straight on the base. Coxites (Fig. 21) elongated, cylindrical and glabrous. Stylus (Fig.21) cylindrical, short, densely pubescent on the apex. Bursa copulatrix (Fig. 21) broad, longer than the vagina, with no sclerites. Spermathecal duct (Fig.21) very short, slightly shorter than the spermatheca, inserted in the ventral middle of the bursa; curved spermathecal capsule, ramus distinct, slightly prominent, collum subequal or slightly shorter than the cornu. Spermathecal gland not observed.

\section{Male}

Aedeagus (Figs. 29 and 30): median lobe slightly shorter than the apodemes; parallel sides, slightly rounded towards the apex; apex slightly rounded with the presence of thin bristles in moderate quantity; curved in profile view. Tegmen (Fig. 39) with short, largely separated dorsal lobes, subequal to the manubrium. Abdominal sternite 8 (Fig. 45) with transversal plates subtriangular, with long thin bristles. 

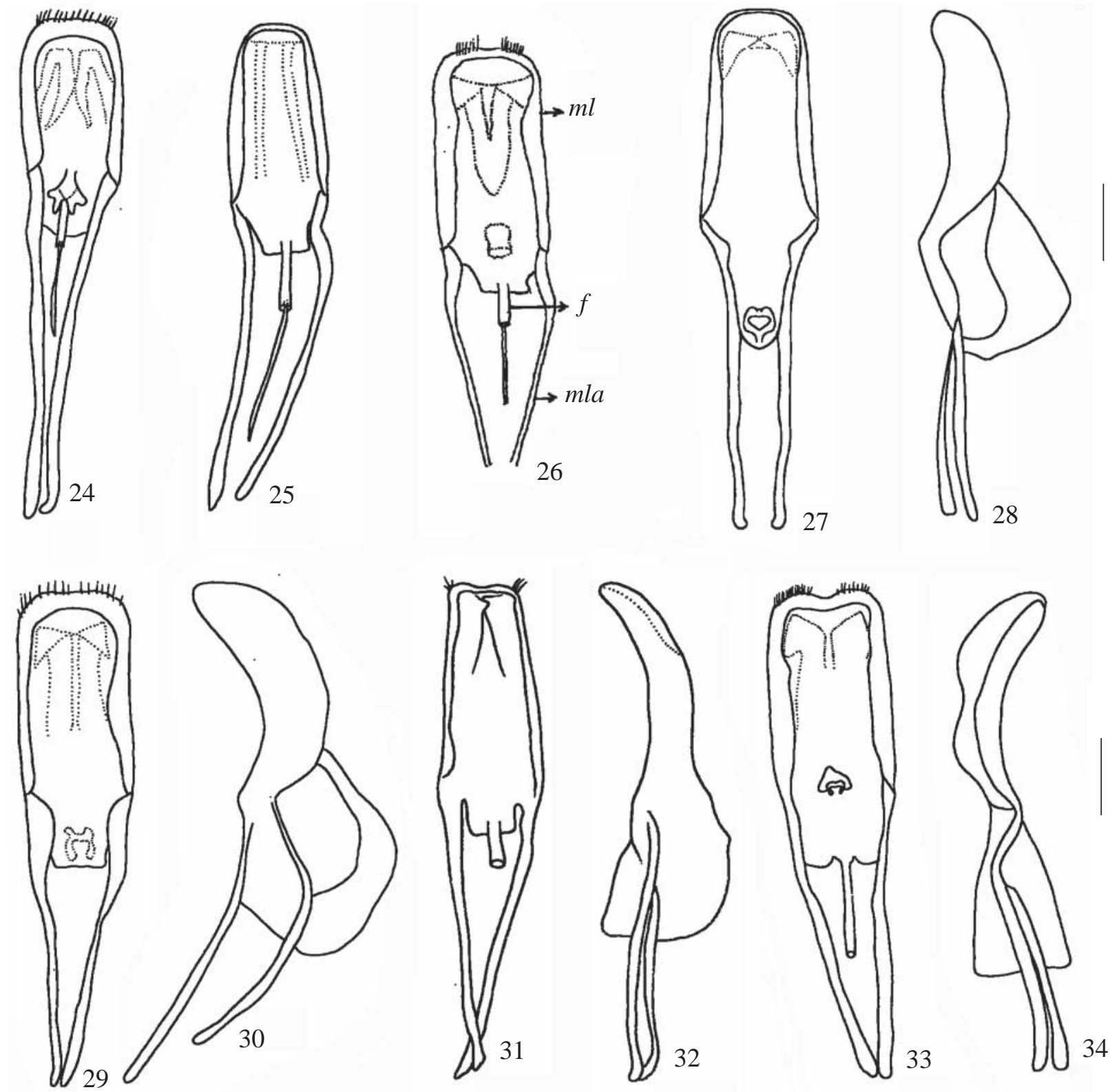

Figs. 24-34. Male genitalia, aedeagus (dorsal and lateral view): 24. H. faldermanni, 25. H. fasciculatus, 26. H. freyreissi, ml: median lobe, f: flagellum, mla: median lobe apodeme, 27,28. H. myops, 29, 30. H. pupillatus, 31, 32. H. rufescens, 33, 34. H. tuberculosus. Bar: $1 \mathrm{~mm}$.

Spiculum gastrale long, wide, slightly curved on the base, apex slightly asymmetric (Fig. 45).

\section{Heilus rufescens (Boheman, 1836)}

(Figs. 6, 13, 22, 31, 32, 40, 46)

Female

Abdominal tergite 8 (Fig. 6) trapezoid, sides slightly converging to the apex; smooth apex and with short, thin and sparse bristles. Abdominal sternite 8 (Fig. 13) with transverse apical lobes, short, rounded sides, dense bristles at the apex; spiculum ventrale narrow. Coxites (Fig. 22) elongated, cylindrical and glabrous. Stylus (Fig. 22) cylindrical, short, densely pubescent at the apex. Bursa copulatrix (Fig. 22) very broad, elongated, about twice as long as the vagina, without sclerites. Spermathecal duct (Fig. 22) extremely short, much shorter than the spermatheca and introduced into the subterminal region of the bursa copulatrix; spermathecal capsule curved, distinct ramus, but slightly protuberant; collum much shorter than the cornu, which is somewhat globular. Spermathecal gland not observed.

\section{Male}

Aedeagus (Fig. 21 and 32): median lobe with the base slightly wider than the apex; slightly shorter than the apodemes; subparallel sides, apical margin sinuous in the median region, with short and thin bristles laterally placed; slightly curved in profile view. Tegmen (Fig. 40) with dorsal lobes broadly separated, subequal to the manubrium Abdominal sternite 8 

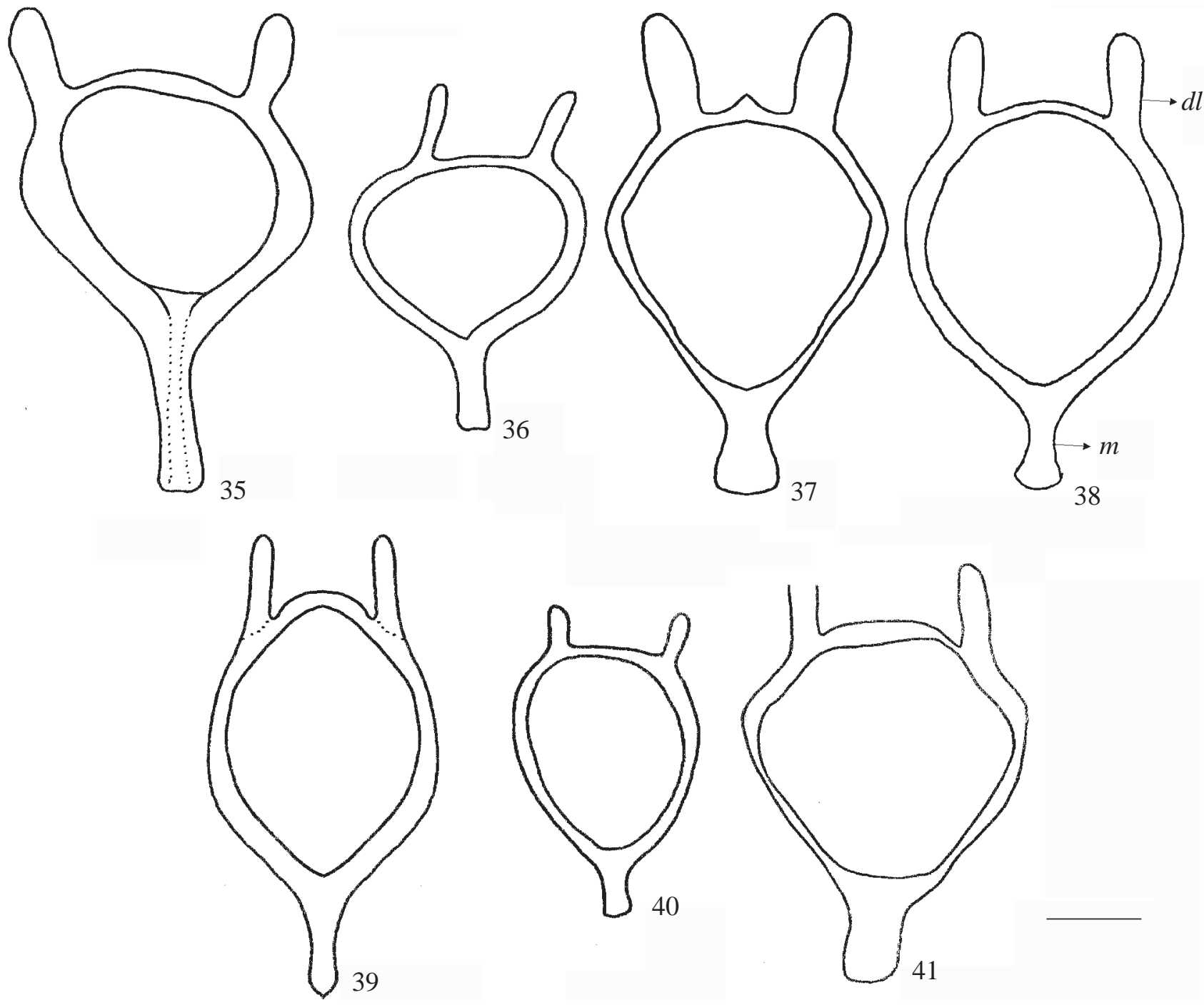

Figs. 35-41. Male genitalia, tegmen (dorsal view): 35. H. faldermanni, 36. H. fasciculatus, 37. H. freyreissi, 38. H. myops, dl: dorsal lobe, m: manubrium, 39. H. pupillatus, 40. H. rufescens, 41. H. tuberculosus. Bar: $1 \mathrm{~mm}$.

(Fig. 46) with transversal plates, apical margin with long and thin bristles. Spiculum gastrale long, narrowed, with the base slightly curved, asymmetric apex (Fig. 46).

\section{Heilus tuberculosus (Perty, 1832)}

(Figs. 7, 14, 23, 33, 34, 41, 47)

\section{Female}

Abdominal tergite 8 (Fig. 7) trapezoid, sides converging to the apex; apical margin crenulate, with short, thin bristles in small quantity. Abdominal sternite 8 (Fig. 14) with elongated apical lobes, rounded near to the apex, pubescent at the apex; spiculum ventrale, with straight base. Coxites (Fig. 23) elongated, cylindrical, glabrous. Stylus (Fig. 23) cylindrical, short, densely pubescent at the apex. Bursa copulatrix (Fig. 23) longer than the vagina, without sclerites. Spermathecal duct (Fig. 23) moderately long, as long as the spermathecal gland and about three times longer than the spermatheca, introduced into the bursa copulatrix base; spermathecal capsule curved, with distinct ramus, collum slightly shorter than the cornu, this somewhat elongated; spermathecal gland membranous, more or less cylindrical and elongated.

\section{Male}

Aedeagus (Figs. 33 and 34): median lobe wide, slightly wider than the apodemes; with internal sclerites; parallel sides, rounded toward the apex; apical margin sinuous in the median region; short, thin bristles, in moderate quantity; curved in profile view. Tegmen (Fig.41) with dorsal lobes broadly separated, short, subequal to the manubrium. Abdominal sternite 8 (Fig. 47) with transversal plates, trapezoid, apical margin with long and thin bristles. Spiculum gastrale wide, rounded at the base, asymmetric apex (Fig. 47).

\section{DISCUSSION}

The female genitalia of the studied species present important diagnostic features that might be useful for species identification and also for establishing the relationship among 

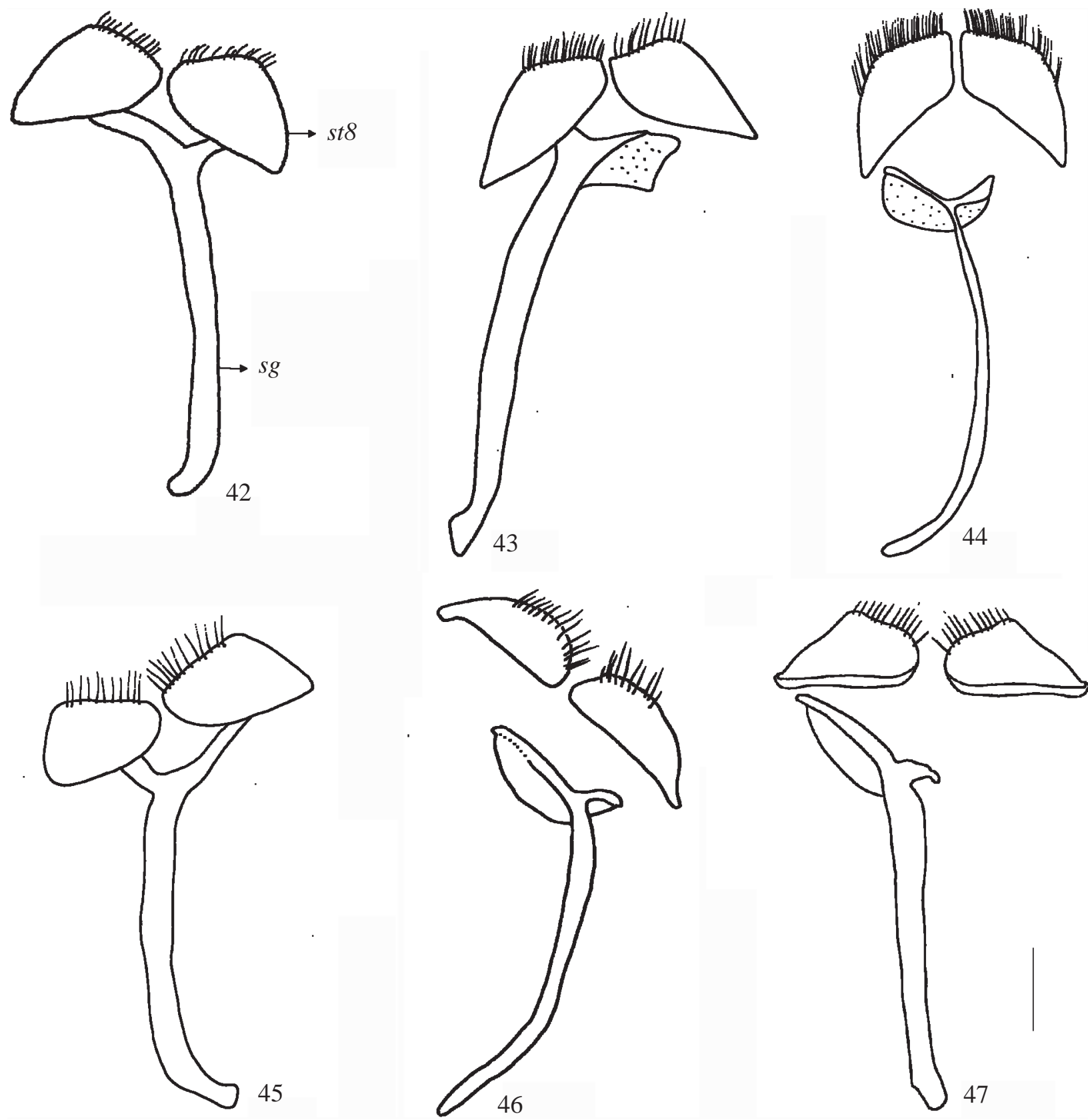

Figs. 42-47. Male genitalia, spiculum gastrale (dorsal view): 42. H. faldermanni, st8: sternite 8, sg: spiculum gastrale, 43. H. fasciculatus, 44. H. freyreissi, 45. H. pupillatus, 46. H. rufescens, 47. H. tuberculosus. Bar: $1 \mathrm{~mm}$.

the genera species. Significant female genitalia features are the length and insertion point of the spermathecal duct in the bursa copulatrix, the development grade of ramus, collum and cornu, presence or absence of bristles on the coxites and eighth tergite apical margin (smooth or crenulate).

The length of spermathecal duct varied from extremely short (H. rufescens), very short (H. faldermanni, $H$. fasciculatus, $H$. freyreissi, $H$. myops and $H$. pupillatus) to moderately long ( $H$. tuberculosus), the length never surpassing the length of the bursa copulatrix. The insertion point of the spermathecal duct may occur in the basal region of the bursa copulatrix near to the common oviduct as in $H$. faldermanni, $H$. freyreissi and $H$. tuberculosus; in the basal region slightly further from the common oviduct, as in $H$. fasciculatus; in the submedian region as in H. pupillatus; or in the subterminal region of the bursa as it occurs in $H$. myops and in $H$. rufescens. The presence of bristles in the coxites was a feature found in only two species, $H$. myops and $H$. faldermanni.

The curved spermatheca is short or elongated as in $H$. faldermanni, distinct or not, and sometimes slightly protuberant. The main variation occurred in the degree of the collum development in relation to the cornu: The collum longer than cornu (H. faldermanni); shorter than the cornu 
(H. fasciculatus, $H$. freyreissi, $H$. myops, $H$. tuberculosus); much shorter than the cornu (H. rufescens); subequal or slightly shorter ( $H$. pupillatus). The spermathecal gland is always elongated.

The abdominal tergite 8 is subtrapezoid, subtransverse, homogeneous in all the species, only more elongated in $H$. fasciculatus; with a smooth apical edge (H. faldermanni, $H$. fasciculatus and $H$. freyreissi), slightly crenulate $(H$. rufescens) or crenulate ( $H$. myops, $H$. pupillatus and $H$. tuberculosus).

The abdominal sternite 8 did not show any expressive variation, the plates are always transverse, triangular or trapezoid, and the apical edge has long, thin bristles, pubescent or with a moderate quantity of bristles.

Regarding the male genitalia, the aedeagus provided the majority of the diagnostic features for the species, such as the presence or absence of bristles on the apex, bristles positioned on the whole apical extension or only laterally and sinuous apical edge in the median region. Absence of bristles in the apical edge of the median lobe in $H$. fasciculatus and $H$. myops; bristles all over the apical edge in $H$. faldermanni and $H$. pupillatus; latero-apical bristles in $H$. freyreissi and $H$. tuberculosus, and more lateral in $H$. rufescens. Apex with an homogeneously rounded edge in $H$. faldermanni, $H$. fasciculatus and $H$. myops; apical edge rounded and sinuous in the middle in $H$. freyreissi; apical edge truncated and sinuous in the middle in $H$. pupillatus, $H$. rufescens and $H$. tuberculosus.

Tegmen quite homogeneous in all species examined, presenting short dorsal lobes and subequal to the manubrium in length; only $H$. faldermanni presents the tegmen with the manubrium about twice as long as the dorsal lobes.

This study corroborates the records presented by Howden (1995, 1996) and Gaiger \& Vanin (2008) with which we totally agree about the necessity of increasing the knowledge related to the female and male genitalia and their associated sclerites (tergite and sternite 8). Undoubtedly, the morphological information and finding of new features will be extremely useful for the recognition of genera and species, as well as for systematic and cladistic studies.

Acknowledgment. To Coordenação e Aperfeiçoamento de Pessoal de Ensino Superior (CAPES) for granting a pos-doctoral fellowship to first author.

\section{REFERENCES}

Gaiger, F. \& S. A. Vanin. 2008. On the utility of female genitalia in the systematics of Curculionidae: examples from Entimini and Hylobiina (Coleoptera: Curculionidae). Annales de la Sociéte Entomologique de France 44: 47-57

Howden, A. T. 1995. Structures related to oviposition in Curculionoidea. Memoirs of Entomolofical Society of Washigton 14: 53-100.

Howden, A. T. 1996. Neotropical Pandeleteius (Coleoptera: Curculionidae) with irregular elytral striae. The Canadian Entomologist 128: 877-955.

Kuschel, G. 1955. Nuevas sinonimias y anotaciones sobre Curculionoidea. Revista Chilena de Entomologia 4: 261-312.

O’Brien, C. W. \& G. J. Wibmer. 1982. Annotated checklist of the weevils (Curculionidae sensu lato) of North America, Central America, and the West Indies (Coleoptera: Curculionoidea). Memoirs of the American Entomological Institute 34: 1-382.

Thompson, R. T. 1992. Observations on the morphology and classification of weevils (Coleoptera, Curculionoidea) with a key to major groups. Journal of Natural History 26: 835-891.

Wanat, M. 2007. Alignment and homology of male terminalia in Curculionoidea and other Coleoptera. Invertebrate Systematics 21: 147-171.

Wibmer, G. J. \& C. W. O’Brien. 1986. Annotated checklist of the weevils (Curculionidae sensu lato) of South America (Coleoptera: Curculionoidea). Memoirs of the American Entomological Institute 39: $1-563$. 